\title{
IQTISHODUNA
}

Vol. 16 (1), 2020

P-ISSN: 1829-524X, E-ISSN: 2614-3437

\section{Studi Etnografi Tentang Perencanaan Keuangan pada Kelompok Sosial Masyarakat Muslim Kota Batu}

\author{
Basir. S 1*, Choirul Rozi 2 \\ 1Sekolah Kajian Stratejik dan Global, Universitas Indonesia, Indonesia \\ ${ }^{2}$ Fakultas Ekonomi, UIN Maulana Malik Ibrahim Malang, Indonesia
}

$\square$ Corresponding Author:

Nama Penulis: Basir.S

E-mail: basir@ui.ac.id

\begin{abstract}
One of the financial successes can be achieved through family financial planning. The purpose of this study is to see how the views of the priyayi Muslim community groups on property. The results of the study show that the views of the household on the priyayi Muslim family in the city of Batu concerning the property are something that is entrusted by Allah SWT. The process of earning an income is that he will strive to make a halal income in terms of the essence, the way to obtain it, and the aspects of His utilization how to determine the priority scale of needs, which is based on the principle of demand and establish themselves from the concept of tabzir or spree on various kinds of needs that they need during their lives. The way to do financial planning is based on a budget management system that applies the concept of Falah in every financial allocation, which is not only focused on the world but also based on the hereafter as well.
\end{abstract}

Keywords: financial planning, financial goals.

\begin{abstract}
Abstrak: Salah satu keberhasilan finansial dapat dicapai melalui perencanaan keuangan keluarga. Tujuan dari penelitian ini adalah untuk melihat bagaimana pandangan kelompok masyarakat Muslim priyayi tentang properti. Hasil penelitian menunjukkan bahwa pandangan rumah tangga pada keluarga Muslim priyayi di kota Batu tentang properti adalah sesuatu yang dipercayakan oleh Allah SWT. Proses mendapatkan penghasilan adalah bahwa ia akan berusaha untuk menghasilkan pendapatan halal dalam hal esensi, cara untuk memperolehnya, dan aspek pemanfaatannya bagaimana menentukan skala prioritas kebutuhan, yang didasarkan pada prinsip menuntut dan memantapkan diri mereka dari konsep tabzir atau mengumbar berbagai macam kebutuhan yang mereka butuhkan selama hidup mereka. Cara melakukan perencanaan keuangan didasarkan pada sistem manajemen anggaran yang menerapkan konsep Falah dalam setiap alokasi keuangan, yang tidak hanya berfokus pada dunia tetapi juga berdasarkan pada akhirat juga.
\end{abstract}

Kata kunci: perencanaan keuangan, tujuan keuangan 
| Draft awal November 2018 |Diterima Februari 2020 | Terbit April 2020 |

| DOI: http: //dx.doi.org/10.18860/iq.v16i1.5828

\section{Cara mencitasi:}

Basir, S., Rozi, C. (2020). Studi Etnografi Tentang Perencanaan Keuangan pada Kelompok Sosial Masyarakat Muslim Kota Batu. Iqtishoduna. Vol. 16 (1): pp 59-72.

\section{Pendahuluan}

Saat ini, pengelolaan keuangan melalui kegiatan perencanaan keuangan adalah salah satu aktivitas yang sangat penting untuk dilakukan oleh setiap individu. Aktivitas perencanaan keuangan yang dilakukan oleh individu merupakan konsep utama di dalam kegiatan pengelolaan keuangan (Ahmed dan Salleh, 2016). Ada beberapa manfaat yang dapat diterima ketika individu dalam suatu rumah tangga menerapkan pengelolan keuangan, salah satunya adalah pengelolaan keuangan yang efektif dan efisien pada nantinya diharapkan akan mampu mendukung terciptanya keluarga yang sejahtera terutama dalam hal pengelolaan keuangan. Kesadaran masyarakat dalam perencaaan keuangan yang berkembang pesat saat ini sejalan dengan inovasi dalam sector keuangan, ketidakpastian dan fluktuasi ekonomi yang tidak menentu seiring dengan meningkatnya permintaan masyarajat dalam hal perencanaan keuangan (Mittra et al., 2005).

Dalam Islam, kita dianjurkan untuk menata kehidupan secara menyeluruh dan holistic, baik itu dalam kehidupan individu maupun kehodupan bermsayarakat, dalam kehidupan spiritual dan materialitis dalam kehidupan saat ini dan kehidupan di masa depan. Dalam syariat Islam, semua kativitas yang dilakukan manusia, termasuk aktivitas ekonomi harus bertujuan untuk mencapai falah, yaitu keberhasilan di dunia maupun di akhirat nantinya, keberhasilan di dunia untuk mencapai kehidupan yang lebih baik dan keberhasilan akhiran untuk mencapai surga (Siddiqi, 1968 dan Ahmed \& Salleh, 2016).

Fungsi ekonomi dan pemenuhan kebutuhan merupakan salah satu dari berbagai macam fungsi dalam kehidupan manusia, individu dan rumah tangga (Pedersen et al., 2013). Dalam kajian Islam, tujuan sebenarnya manusia adalah kesejahteraan (falah) (Ahmad \& Salleh, 2016). Falah 
mengandung makna sebagai kesuksesan, kemenangan serta kemuliaan. Falah dapat diartikan sebagai kesuksesan yang sifatnya jangka panjang, meliputi dimensi materi serta dimensi spiritual. Falah dapat dengan mudah diraih ketika kebutuhan dasar individu sudah terpenuhi, maka falah akan dengan mudah diwujudkan. Dalam Islam, sebaiknya penggunaan harta yang kita miliki hendaknya mengarah pada tujuan kemakmuran dan kemaslahatan demi agama, ilmu pengetahuan, keturunan, jiwa dan harta benda yang dimiliki.

Dalam kehidupan sehari hari, banyak individu dan rumah tangga yang sudah menjalankan kegiatan perencanaan keuangan dalam kehidupan sehari hari. Dalam membangun perencaan keuangan keluarga, Campbell (2006) menuturkan beebrapa hal yang perlu untuk diperhatikan, antara lain : a) menentukan potensi keuangan untuk periode saat ini dan periode masa depan, 2) menentukan tujuan perencanaan dan pengelolaan keuangan dalam jangka pendek dan jangka panjang, 3) membuat catatan sederhana tentang arus uang yang masuk dan arus uang yang keluar, 4) mampu untuk mengidentifikasi resiko dalam setiap keputusan investasi, serta 5) mampu mengenal secara tepat model model dalam pengelolaan dan perencanaan keuangan. Indikator dalam pengelolaan dan perencanaan keuangan adalah tentang kemampuan individu untuk melakukan pencatatan atas laporan keuangan yang sederhana (Lai \& Tan, 2009).

Tujuan penelitian ini pada khususnya adalah untuk menganalisis tentang bagaimana perilaku sekelompok masyarakat muslim yang ada di Kota Batu tentang perilakunya dalam melakukan perencanaan euangan rumah tangga untuk tujuan maksimalisasi tujuan finansial. Masyarakat Jawa (Geertz, 1981) menyatakan tiga tipologi masyarakat Jawa. Tipologi yang pertama adalah masyarakat santri, kedua kelompok masyarakat abangan, dan ketiga adalah kelompok masyarakat priyayi.

Ketiga kelompok masyarakat tersebut dapat secara rinci dijabarkan sebagai berikut. Kelompok masyarakat santri adalah kelompok masyarakat yang identik dengan masyarakat dari golongan niaga atau berdagang, petani dimana mereka bermukim di perkotaan, yang sangat dekat dengan tempat ibadah. Tipologi kedua adalah masyarakat abangan. Masyarakat abangan secara umum merupakan masyarakat kelompok petani yang bermukim di daerah pedesaan atau bahkan lereng gunung, yang mereka notabenya sangat sedikit berinteraksi dan bahkan mendapat pengaruh dari dunia luar. Kelompok masyarakat yang ketiga adalah, masyarakat birokrasi, yaitu masyarakat yang kehidupan sehari harinya berhubungan dengan aktivitas 
birokrasi. Menurut Geertz (1981), kelompok masyarakat yang ketiga ini merupakan kelompok masyarakat yang menempati posisi teratas dalam pembagian kelompok masyarakat di Jawa.

Dalam perencanaan keuangan dalam rangka memaksimalkan tujuan finansial sangatlah penting untuk dikaji. Secara khusus, motivasi dalam penelitian ini antara lain a) penting untuk memperhatikan tentang pandangan kelompok masyarakat priyayi di Kota Batu tentang konsep harta benda, b) untuk mengatahui bagaimana proses mendapatkan penghasilan, pengelolaannya, serta perencaaan keuangan sehari hari mereka, c) tujuan ketiganya adalah untuk mengembangkan hasil penelitian terdahulu dengan menggunakan metode, objek serta alat analisis yang berbeda, d) motivasi keempat dalam penelitian ini untuk melakukan pembaruan terhadap penelitian sebelumnya dengan memberikan hasil dan bukti secara empiris dengan objek penelitian yang berbeda ditinjau dari aspek agama dan aspek etika.

\section{Kajian Pustaka}

\section{Perencanaan Keuangan (Financial Planning)}

Pengertian perencanaan keuangan merupakan sebuah aktivitas yang dilakukan untuk mampu menggapai tujuan dalam hidupnya yang dapat dilakukan dengan jalan melakukan perencanaan keuangan dan manajemen keuangan yang baik (Certified Financial Planner, 2007). Perencanaan keuangan dapat juga diartikan sebagai kegiatan untuk merencanakan pengelolaan keuangan secara cermat (Budisantoso \& Gunanto, 2010). Dalam kehidupan tentunya kita memiliki investasi jangka panjang atau keinginan di masa yang akan datang, misalnya membeli rumah, memiliki tabungan, deposito, Pendidikan anak, dimana kesemua aktivitas itu dapat terpenuhi salah satunya dengan cara melakukan pengelolaan keuangan. Dalam Islam, kondisi ketidakpastian yang kita hadapi mengharuskan kita untuk melakukan perencanaan keuangan dengan benar, akrena dalam menjalani hidup kita, semuanya adalah titipan dari Allah SWT.

\section{Pengelolaan Keuangan Pribadi (Personal Finance)}

Pengelolaan keuangan pribadi merupakan suatu aktivitas perencanaan keuangan oleh individu dengan tujuan untuk mampu meraih dan mampu memenuhi segala keinginan dan kebutuhan baik secara pribadi maupun keuangan keluarga. Perencanaan keuangan individu menurut Endrianti (2016) dapat dibedakan menjadi dua kelompok, yaitu kegiatan perencanaan yang mencakup semua jenis kebutuhan serta kegiatan perencaan keuangan yang hanya mencakup pada jenis jenis kebutuhan tertentu saja. 


\section{Perencanaan Keuangan Muslim}

Ketika melakukan perencanaan keuangan, seorang muslim hendaknya memperhatikan beberapa hal (Ahmed dan Salleh, 2016):

a. Zakat. Rezeki yang telah kita dapatkan, sebagiannya terdapat hak hak orang lain, dimana kita sebagai umat Muslim diwajibkan untuk mengeluarkannya. Sehingga dalam mendapatkan harta, kita wajib untuk membersihkannya melalui aktivitas zakat, infaq, sedekah maupun wakaf.

b. Asuransi. Dalam setiap aktivitas yang kita lakukan tidak akan luput dari resiko. Demikian pula dengan pendapatan yang kita hasilkan juga akan menghadapi resiko.

c. Konsumsi saat ini (present consumtion), yaitu berupa sejumlah penghasilan yang digunakan secara wajar.

d. Konsumsi masa yang datang (future spending), yaitu berupa penghasilan yang digunakan di masa depan dengan menabung.

e. Investasi. Investasi dapat dilakukan sebagai bentuk kegiatan pemenuhan kebutuhan serta keinginan jangka panjang.

\section{Sikap di dalam Memanfaatkan Harta dan Uang}

Harta yang kita dapatkan adalah hak milik kita, dimana pengelolaannya dapat digunakan saat dibutuhkan. Dalam Islam, harta dapat diartikan sebagai segala sesuatu yang merupakan milik Allah.Kita manusia adalah pembawa amanah, untuk itu kita diharuskan dapat memanfaatkan harta secara efektif dan efisien. Harta yang didapatkan merupakan harta dimana didalamnya terdapat hak hak kaum tidak mampu, oleh sebab itu wajib bagi kita untuk tidak melalaikan hak hak orang lain tersebut, untuk dapat menginfakkan sebagain harta kita untuk orang lain, karena harta yang kita miliki bukanlah bekal kita nantinya di akhirat, namun harta adalah sarana untuk menggapai surga di akhirat.

\section{Metodologi Penelitian}

Objek penelitian di dalam penelitian ini yaitu kelompok masyarakat birokrasi di Kota Batu. Teknik pengambilan informan penelitian yang digunakan adalah dengan menggunakan purposive, yaitu menentukan subyek penelitian dengan menggunakan kriteria, antara lain: (a) Kelompok masyarakat priyayi muslim; (b) mereka memiliki 2 anak; (3) bekerja dalam ruang lingkup birokrasi minimal 10 tahun; (4) dari kriteria yang telah ditentukan, akhirnya didapatkan 10 rumah tangga muslim sebagai informan yang memenuhi kriteria sebagai subyek penelitian.

IQTISHODUNA Vol. 16 (1), 2020 | 63 
Basir, S., Choirul Rozi

\section{Gambaran Singkat Objek Penelitian}

Objek penelitian dalam penelitian itu berada di Kota Batu. Kota Batu ditetapkan sebagai kota administrative pada tanggal 6 Maret 1993. Kota Batu sebelumnya adalah bagian dari Kabupaten Malang. Pada tanggal 17 Oktober 2001, Kota Batu ditetapkan sebagai kota otonom. Kota Batu, yang saat ini dijuluki sebagai KWB (Kota Wisata Batu). Kota Batu berkembang sangat pesat serta terkemuka dan menajdi tujuan utama wisatawan saat berkunjung di Jawa Timur, yang memiliki potensi keindahan alam yang liuar biasa ditambah dengan udara yang sejuk. Bahkan Kota Batu saat ini disandingkan. Bahkan saat ini Kota Batu dijuluki sebagai Swiss kecil di Pulau Jawa.

Kota Batu posisinya terletak pada dataran tinggi dengan ketinggian 700-1.700m dpl. Dari sejarah yang berkembang, sebutan Batu berasal dari nama seorang ulama yaitu Kyai Gubug Angin yang lebih dikenal sebagai Mhan Waatu. Kebiasaan di Jawa adalah dimana orang sering memperpendek sebuah kata untuk mempermudah mengingatnya agar tidak terlalu panjang, sehingga lambat laun disebut sebagai Mbah Wastu menjadi Mbah Tu lalu selanjutnya disebut dengan Mbatu.

\section{Hasil Penelitian}

\section{Pandangan tentang Harta Benda}

Secara etimologis, harta dapat dimaknai sebagai al-mal. Artinya cenderung, condong dan miring. Adapun secara etimologi (Nawawi, 2012) oleh madzhab hanafi adalah sesuatu yang paling disukai oleh manusia agar dapat disimpan dan dibutuhkan. Harta kekayaan adalah sesuatu hal yang tidak terpisahkan dalam hidup manusia. Di dalam mencapai kesejahteraan hidupnya di dunia mulai dari lahir sampai akhir hayatnya akan selalu didampingi oleh harta. Harta dapat diartikan sebagai sesuatu yang berwujud serta disimpan sehingga semua yang sifatnya tidak berwujud serta tidak dapat disimpan tidak tergolong di dalam harta. Menurut para ahli fikih, susunan harta bersendi pada dua unsur, yaitu unsur 'aniyah dan unsur 'urf. Unsur 'aniyah dapat dimakani sebagai harta yang memiliki wujud secara nyata dapat dilihat.

Unsur 'aniyah adalah harta yang harus memiliki wujud secara nyata (a'yan). Unsur 'urf adalah segala sesuatu yang dilihat harta oleh seluruh atau sebagian manusia (Nawawi, 2012). Dijelaskan dalam Al-qur'an bahwa harta ialah perhiasan dalam kehidupan, terdapat dalam Qs. Al-Kahfi ayat 46: Artinya: "Harta dan anak-anak adalah perhiasan kehidupan dunia tetapi 
amalan-amalan yang kekal lagi saleh adalah lebih baik pahalanya di sisi Tuhanmu serta lebih baik untuk menjadi harapan".

Konsekuensi logis ayat-ayat yang telah diuraikan adalah sebagai berikut:

Manusia bukanlah pemilik mutlak, namun mereka dibatasi oleh hak yang dimiliki Allah, sehingga hal ini menjadi sebuah kewajiban untuk manusia mengeluarkan sebagian harta yang mereka miliki kepada mereka golongan yang berhak. Harta yang dimiliki oleh individu, boleh digunakan untyk umum dengan syarat dimana pemiliknya mendapatkan imbalan yang wajar. Berdasar gambaran di atas, dapat ditarik kesimpulan bahwa harta merupakan titipan dari Allah SWT yang dapat diperoleh dengan usaha yang baik dan halal serta dapat diambil manfaatnya untuk kehidupan dalam upaya kemakmuran bersama dan tidak maksud untuk mengeksploitasinya dalam kehidupan pribadi karena ada hak orang lain terhadap harta yang kita peroleh.

Harta merupakan sesuatu yang dititipkan oleh Allah SWT kepada hamba-Nya, yang dalam penggunaannya manusia hanya sebagai pemegang amanah yang diberikan-Nya untuk digunakan sebagai bekal dalam beribadah di muka bumi Allah SWT. Sehingga akan kembali pada sang pemilik titipan dan segala gerak dan aktivitas-aktivitas rumah tangga pada keluarga muslim priyayi di kota Batu, ia akan mengingat-mengingat kembali bagaimana cara harta itu di dapat, dan diambil manfaatnya untuk kehidupannya sendiri dan orang lain sehingga dalam penggunaannya selalu berlandaskan pada aturan Allah SWT yaitu Al-Qur'an dan berlandaskan pula pada sunnah Nabi Muhammad SAW.

\section{Proses Mendapatkan Penghasilan}

Manusia menjalani kehidupan tentunya membutuhkan sebuah penghasilan unuk dapat memenuhi kebutuhan dalam hidupnya. Allah SWT sebagai penjamin rezeki manusia kapanpun dan dimanapun, sebab Allah adalah Maha Pemberi rezeki. Akan tetapi rezeki tersebut harus diusahakan oleh manusia. Allah telah menciptakan berbagai sarana dan prasana untuk mendukung berbagai usaha manusia dalam mencari rezeki.

Beberapa hasil percakapan dengan para informan kunci yang menunjukkan pemahaman mereka terhadap proses mendapatkan penghasilan:

mendatangkan berbagai rezeki dan membuatnya sangat mudah untuk dicapai serta penuh dengan limpahan berkah melalui tawakal yang sejati dan berusaha secara maksimal. (HES) 
Basir, S., Choirul Rozi

kalau saya, untuk memenuhi segala kebutuhan rumah tangga "ya harus selalu berusaha mas, kalau kebanyakan orang bilang selalu ikhtiar. Tapi, semua itu nyata harus diikuti aturan yang telah ditentukan oleh Gusti Alloh. (HNT)

mencari rezeki, carilah rezeki yang halal dan tidak berseberangan dengan syariat. Rezeki yang kita dapat tersebut nantinya juga akan kita konsumsi. Apabila baik, Insyaallah akan memberikan dampak yang baik. (HPR)

Aturan yang sudah ditentukan oleh syariat agama itulah diterapkan dalam rumah tangga pada keluarga muslim priyayi di kota Batu, yakni dengan melakukan kegiatan ekonomi yang berlandaskan pada konsep ekonomi Islam. Diantara aturan ini adalah sebagaimana yang termaktub dalam firman Allah SWT dalam Qs. Al-Baqarah ayat 168:

Artinya: "Hai sekalian manusia, makanlah yang halal lagi baik dari apa yang terdapat di bumi, dan janganlah kamu mengikuti langkah-langkah syaitan; karena sesungguhnya syaitan itu adalah musuh yang nyata bagimu".

Berdasarkan penjelasan yang telah dipaparkan, didapatlah bahwa sikap Islam terhadap hak milik adalah:

a. Mengakui dan menghormati keberadaannya.

b. Mengakui dan menghormati serta mengatur tentang hak milik tersebut.

c. Penghormatan Islam terhadap hak milik itu jelas dalam penghormatannya terhadap harta benda sebagai tuntutan hak milik itu.

d. Penghormatan terhadap hak milik itu secara syariah sesuai konsep maqasidus-syariah.

e. penghormatan terhadap hak milik itu secara syariah melarang orang melakukan pelanggaran ketentuan-ketentuan mengenai harta tersebut (Nawawi, 2012).

Menurut rumah tangga pada keluarga muslim priyayi di kota Batu, mereka menggunakan konsep penghasilan halal sesuai dengan konsep cara mengkonsumsi makanan dengan kriteria halal. Hasil wawancara dengan informan (HBS), yakni:

kita sebagai umat yang beragama dan betul-betul dalam hidup melaksanakan sareat yang benar, maka dalam mendapatkan materi kita harus senantiasa memperhatikan zat, perolehnya, dan penggunaannya.................(HBS)

Penghasilan yang semula halal akan berubah menjadi haram apabila pekerjaan yang dalam upaya mendapatkan penghasilan tersebut dengan

66 | IQTISHODUNA Vol. 16 (1), 2020

http://ejournal.uin-malang.ac.id/index.php/ekonomi 
cara yang tidak sah atau tidak diperbolehkan secara syariat Islam. Oleh sebab itu, untuk memperoleh penghasilan yang halal hendaknya menggunakan cara yang dibenarkan oleh syariat. Diantaranya dengan bertani, berdagang, menjadi pekerja bangunan, atau menjual jasa, dan lain sebagainya (Djakfar, 2013). Syariah tidak hanya memberikan ketentuan dengan nash-nash yang sangat umum saja, tetapi menerangkan ketentuanketentuan yang khusus tentang macam-macam bentuk pelanggaran. Islam mengharamkan mengambil harta orang secara tidak benar, Oleh karena itu, rumah tangga pada keluarga muslim priyayi, ia akan berupaya untuk memperoleh penghasilan yang halal dari segi dzatnya, cara perolehannya, dan segi pemanfaatan-Nya.

\section{Menentukan Skala Prioritas}

Dalam kehidupan ekonomi, sangat penting bagi manusia untuk menyusun skala prioritas. Hal tersebut berfungsi untuk mengelola keuangan keluarga agar berjalan sesuai dengan apa yang diharapkan keluarga. Efisiensi dan efektivitas merupakan landasan fundamental dalam proses pengambilan keputusan dalam pengeluaran rumah tangga pada keluarga muslim priyayi di kota Batu. Menurut Chapra, komitmen terhadap nilai-nilai Islam dan maqashid syariah harus diterapkan. Maqashid syariah akan membantu terutama dalam mengurangi penyalahan keputusan dalam melakukan pengeluaran keluarga dengan memberikan kriteria untuk membangun prioritas. Berdasar hasil wawancara dari informan bahwa:

sejak kami berumah tangga, kami sangat menyadari betapa sangat perlunya dilakukan perencanaan keuangan rumah tangga. Apa lagi waktu diawal menikah dulu penghasilan masih terbatas, maklum masi golongan awal-awal. Maka, pencatatan kebutuhan yang ada akan setiap bulannya akan menghindarkan dari kelupaan belanja pokok (MMK)

walaupun saya sudah PNS golongan tiga dan alhamdulillah Bapaknya anak-anak juga PNS, tapi saya sebagai ibu rumah tangga menyadari bahwa belanja boros-boros itu tidak baik, jadi ya kita utamakan yang penting-penting saja, tapi ya tidak pelit juga "sambil tersenyum dan tertawa" artinya bahwa kita lebih mengutamakan kebutuhan dari pada keinginan. (MDN)

Mencatat semua kebutuhan yang ada merupakan bentuk upaya dari penyusunan daftar skala prioritas. Di dalam Islam, konsep mencatat semua kebutuhan yang ada dengan rapi, tingkat kebutuhan adalah penting untuk dilakukan. Pencatatan ini dibutuhkan untuk memudahkan kita dalam mengingat berbagai jenis dan macam kebutuhan. Sehingga ketika sudah 
Basir, S., Choirul Rozi

tercatat, kita akan mampu melakukan bentuk evaluasi pencatatan. Membuat urutan kebutuhan berdasarkan tingkat kebutuhannya merupakan suatu urutan yang penting dalam langkah penyusunan skala prioritas. Kita mampu melakukan manajemen operasional berkenaan dengan barang-barang atau kebutuhan yang sifatnya terbagi dalam empat mode, yakni: (a) Penting dan mendesak. (b) Penting dan tidak mendesak. (3) Tidak penting dan mendesak. (4) Tidak penting dan tidak mendesak.

Mekanisme ini sangatlah diharuskan untuk dilakukan. Mendahulukan kebutuhan dibandingkan keinginan adalah hal yang sangat baik untuk dilakukan. Sedang mendahulukan keinginan dibandingkan kebutuhan adalah hawa nafsu. Hal ini merupakan bentuk pencegahan dari sifat boros. Pernyataan terkait sikap tentang skala prioritas dari informan kunci:

diupayakan pengeluaran rumah tangga pada kebutuhan yang mendesak agar dapat terpenuhi dan tidak mengganggu pengeluaran yang lain. Uang teralokasikan dapat bermanfaat dengan baik. (ISN)

Imam Al-Ghozali berpendapat bahwa keinginan individu untuk bisa mendapatkan sesuatu dalam hidupnya guna kelangsungan hidup sehari hari serta menjalankan aktivitasnya sebagai hamba Allah adalah dengan jalan secara maksimal. Beribadah kepada Allah hukumnya bagi setiap muslim adalah wajib. Setiap manusia harus selalu berusaha untuk dapat memenuhi kebutuhannya agar kewajiban utama untuk beribadah secara maksimal dapat terlaksana dengan baik.

Berdasar pada wawancara mendalam pada informan (PSD):

adanya pencatatan kebutuhan yang dilakukan ibu rumah tangga sangatlah penting. Karena apabila nantinya kekurangan dana, salah satu cara mengatasinya adalah dengan hutang. Tapi, masa kita harus seringsering hutang, ya....pasti ada malu juga kan. (PSD)

Memilih catatan kebutuhan yang paling memberi manfaat secara optimal merupakan suatu urutan yang penting dalam langkah penyusunan skala prioritas. Dalam proses ini adalah melakukan pemilihan-pemilihan kebutuhan yang harus dipenuhi dengan segera. Pada tahap ini merupakan tahap setelah melakukan alokasi dana, dimana adanya alokasi dana tersebut akan di porsikan pada kebutuhan yang memberikan manfaat secara optimal. Di dalam Islam konsep peminjaman dana (hutang) adalah boleh namun, sebaiknya dihindarkan. Dan juga terdapat dalam Qs.Al-A'raf ayat 31:

Artinya: "Hai anak Adam, pakailah pakaianmu yang indah di setiap (memasuki) mesjid, makan dan minumlah, dan janganlah berlebih-lebihan. 
Sesungguhnya Allah tidak menyukai orang-orang yang berlebih-lebihan".

Prinsip utama membuat skala prioritas pada rumah tangga pada keluarga muslim priyayi di Kota Batu adalah berdasarkan pada asas kebutuhan dan menjuauhkan diri dari konsep tabzir atau foya-foya terhadap berbagai macam kebutuhan yang mereka butuhkan selama melangsungkan kehidupannya. Rumah tangga muslim priyayi mempercayai bahwa tujuan utama untuk memenuhi kebutuhan di dalm hidupnya adalah untuk beribadah dan mencapai keridhoannya. Sebab, rumah tangga pada keluarga muslim priyayi di Kota Batu dalam mengatur dan membuat rancangan skala prioritas atas berbagai macam kebutuhannya adalah untuk menekan alokasi dana dalam penggunaan kebutuhan yang bersifat tidak penting dan tidak mendesak.

Upaya pengelolaan keuangannya, rumah tangga pada keluarga muslim priyayi di kota Batu adalah dengan membuat daftar skala prioritas. Skala prioritas kebutuhan ini dimaksudkan untuk sebagai dasar pengeluaran keuangan yang berorientasi pada kebutuhan yang sifatnya penting dan mendesak (dharuriyah) bukan berorientasi pada keinginan semata serta mendahulukan konsep islah (pengutamaan sebuah kebermanfaatan dan berusaha mengurangi keinginan yang berlebihan).

\section{Membuat Perencanaan Keuangan Rumah Tangga}

Hasil wawancara mendalam dengan informan kunci tentang perencanaan keuangan rumah tangga adalah sebagai berikut:

rezeki yang kita dapat itu ada juga hak orang lain, yang dimana kita wajib mengeluarkannya. Cara mengeluarkannya dapat dilakukan seperti zakat. Ada pengamen lewat depan rumah ya, ya diberi Rp500 atau Rp1000. (MIP)

...kedepannya, kehidupan ini kan kita tidak tahu seperti apa. Kita bisa saja mengalami musibah. Ya, sebaiknya kita perlu juga melakukan asuransi. (HES)

sebaiknya konsumsi yang dilakukan itu yang sederhana. Tidak mengikuti hawa nafsu untuk menghabiskan semua keuangan dialokasikan untuk konsumsi. (USM)

nantinya kan, kita punya anak-anak pasti akan sekolah, paling tidak sampai sarjanalah. Jadi kita perlu menabung dan investasi walaupun nilainya kecil. Lama-lama kan juga jadi banyak. Insyaallah kedepan pasti akan membantu biaya pendidikan anak. (HES) 
Salah satu tahapan dalam proses perencanaan keuangan yang perlu diperhatikan adalah bagaimana cara menyusun anggaran dalam rumah tangga. Anggaran rumah tangga yang baik dan sehat adalah dimana jumlah uang yang kita keluarkan sama atau bahkan jauh lebih besar dari jumlah uang yang masuk. Konsep pemasukan dan pengeluaran harus sangat diperhatikan dalam kegiatan mengelola keuangan di dalam suatu rumah tangga. Jikasetiap individu dapat melakukan kegiatan pengelolaan keuangan rumah tangga dengan efektif dan efisien, ada beberapa keuntungan yang akan mereka dapatkan, diantaranya: Secara rinci, individu akan mampu memonitor jumlah uang yang keluar dan masuk dalam rumah tangga; Perencanaan anggaran yang dibuat dijadikan sebagai pedoman di dalam kegiatan pengelolaan keuangan di dalam rumah tangga, sehingga kita individu dalam rumah tangga dapat menentukan prioritas, serta mampu untuk menyisihkan sebagian harta dari harta yang kita hasilkan untuk orang lain sesuai dengan haknya.

Di masa depan, kita tidak bisa memastikan kebutuhan apa saja yang kita inginkan yang semuanya penuh dengan ketidakpastian. Resiko akan selalu mengintai kita dengan segala aktivitas yang kita lakukan, termasuk dengan aktivitas keuangan, sehingga penting bagi kita melalukan perencaan keuangan yang baik (Xiao et al., 2006). Keuangan keluarga yang tertata secara efektif dan efisien, sehingga keluarga tersebut secara finansial akan dapat memudahkan dalam memenuhi kebutuhannya dengan baik. Keuangan atau finansial di katakan sukses, apabila dilengkapi dengan perencanaan yang matang mengenai kebutuhan finansial dari keluarga tersebut. Konsep pembangunan dan perencanaan keuangan yang digunakan oleh rumah tangga muslim adalah mengacu pada konsep falah sebagai tujuan hidupnya. Konsep falah ini merupakan konsep yang mengandung makna kemuliaan dan kemenangan. Makna kemuliaan dan kemenangan adalah kehidupan di dunia serta kehidupan di akhirat yang dapat dijelaskan dalam Qs. Ali-Imron ayat 3:

Artinya: "Dan hendaklah ada di antara kamu segolongan umat yang menyeru kepada kebajikan, menyuruh kepada yang ma'ruf dan mencegah dari yang munkar; merekalah orang-orang yang beruntung”.

Perencanaan keuangan rumah tangga pada keluarga muslim priyayi di kota Batu adalah berdasarkan pada sistem manajemen anggaran yang menerapkan konsep falah dalam setiap alokasi keuangan yakni tidak hanya berfokus pada dunia saja akan tetapi juga berdasarkan pada akhirat juga. Diantara yang mereka lakukan adalah membagi keuangan dalam kelompok pemenuhan kebutuhan duniawi, seperti kebutuhan sehari-hari, biaya 
pendidikan anak, asuransi dan menabung. Sedangkan pada kebutuhan akhirat seperti zakat, infaq, sedekah dan ibadah lainnya ketika hari raya.

\section{Kesimpulan}

Pandangan rumah tangga pada keluarga muslim priyayi di kota Batu mengenai harta yaitu sesuatu yang diberikan oleh Allah SWT kepada kita, serta dalam penggunaannya manusia hanya sebagai pemegang amanah yang diberikan-Nya untuk digunakan sebagai bekal dalam beribadah di muka bumi Allah SWT. Sehingga akan kembali pada sang pemilik titipan amanah tersebut yakni Allah SWT.

Pandangan rumah tangga pada keluarga muslim priyayi di kota Batu mengenai proses mendapatkan penghasilan yaitu ia akan berupaya untuk memperoleh penghasilan yang halal dari segi dzatnya, cara perolehannya, dan segi pemanfaatann-Nya. Sebab segala sesuatu yang berkenaan dengan apa yang akan di konsumsi manusia dapat dijelaskan dalam AL Qur`an dan Hadist.

Pandangan rumah tangga pada keluarga muslim priyayi di kota Batu mengenai cara menentukan skala prioritas kebutuhan yaitu berdasarkan pada asas kebutuhan dan menjuauhkan diri dari konsep tabzir atau foyafoya terhadap berbagai macam kebutuhan yang mereka butuhkan selama melangsungkan kehidupannya.

Pandangan rumah tangga pada keluarga muslim priyayi di kota Batu mengenai cara membuat perencanaan keuangan yaitu dengan berdasarkan pada sistem manajemen anggaran yang menerapkan konsep falah dalam setiap alokasi keuangan yakni tidak hanya berfokus pada dunia saja akan tetapi juga berdasarkan pada akhirat juga.

\section{Daftar Pustaka}

Al-Qur'an. Terjemahannya (Revisi terbaru) Departemen Agama RI dengan transletisasi Arab-Latin. (2001). Semarang: CV. Asy Syifa.

Ahmed, H. and Salleh, A. (2016). Inclusive Islamic financial planning: a conceptual framework", International Journal of Islamic and Middle Eastern Finance and Management. Vol. 9(2). Pp: 170-189. https://doi.org/10.1108/IMEFM-01-2015-0006

Budisantoso, I \& Gunanto. (2010). Cara Gampang Mengelola Keuangan Pribadi dan Keluarga. Hal: 11. Jakarta: PT Gramedia. 
Basir, S., Choirul Rozi

Campbell, J. (2006). Household finance. Journal of Finance. 61. Pp: 15531604.

Certified Financial Planner Board of Standards. (2013). Financial Planning Profiles of American Households: The 2013. Household Financial Planning Survey and Index. A Summary of Key Findings. Certified Financial Planner Board of Standards, Inc. and the Consumer Federation of America.

Endrianti, R. D \& Nisful, L. (2016). Pengelolaan Keuangan Keluarga Secara Islam Pada Keluarga Muslim Etnis Padang Dan Makassar Di Surabaya. Jurnal Ekonomi Syariah Teori dan Terapan Vol. 3 (7). Pp: 549-560.

Geertz, Clifford. (1981). Abangan, Santri, Priyayi dalam Masyarakat Jawa, terjemahan. Aswab Mahasin, Bandung: Dunia Pustaka Jaya.

Lai, M.M. and Tan, W. (2009). An Empirical Analysis of Personal Finance Planning in an Emerging Market. European Journal of Economics, Finance and Administrative Sciences. 16. Pp:102 -115.

Mittra, S., Potts, T. and LaBrecque, L. (2005). Practicing Financial Planning for Professionals, RH Publishing, MI.

Nawawi, I. (2012). Fikih Muamalah. Bogor: Penerbit Ghalia Indonesia.

Pedersen, Anne Marie B., Alex Weissensteiner and Rolf Poulsen. (2013). Financial planning for young households. Annals of Operations Research. Volume 205(1). Pp: 55-76.

Rajna, A., Ezat, WP. S., Junid, S. A. and Moshiri, H. (2011). Financial Management Attitudes and Practice among the Medical Practitioners in Public and Private Medical Service In Malaysia. International Journal of Business and Management. 6 (8). Pp: 105 - 113.

Siddiqi, M.N. (1996). Role of the State in the Economy: An Islamic Perspective, The Islamic Foundation, Leicester.

Xiao, J.J., Sorhaindo, B. and Garman, E.T. (2006). Financial behaviours of consumers in credit counseling. International Journal of Consumer Studies. Vol. 30 (2). Pp: 108-121. 